\title{
FERNÁNDEZ PEQUEÑO, ENTRE LOS LÍMITES DEL BARRIO Y EL MUNDO
}

\section{Fernández Pequeño, between the limits of the neighborhood and the world}

\section{Ena Columbié ${ }^{1}$}

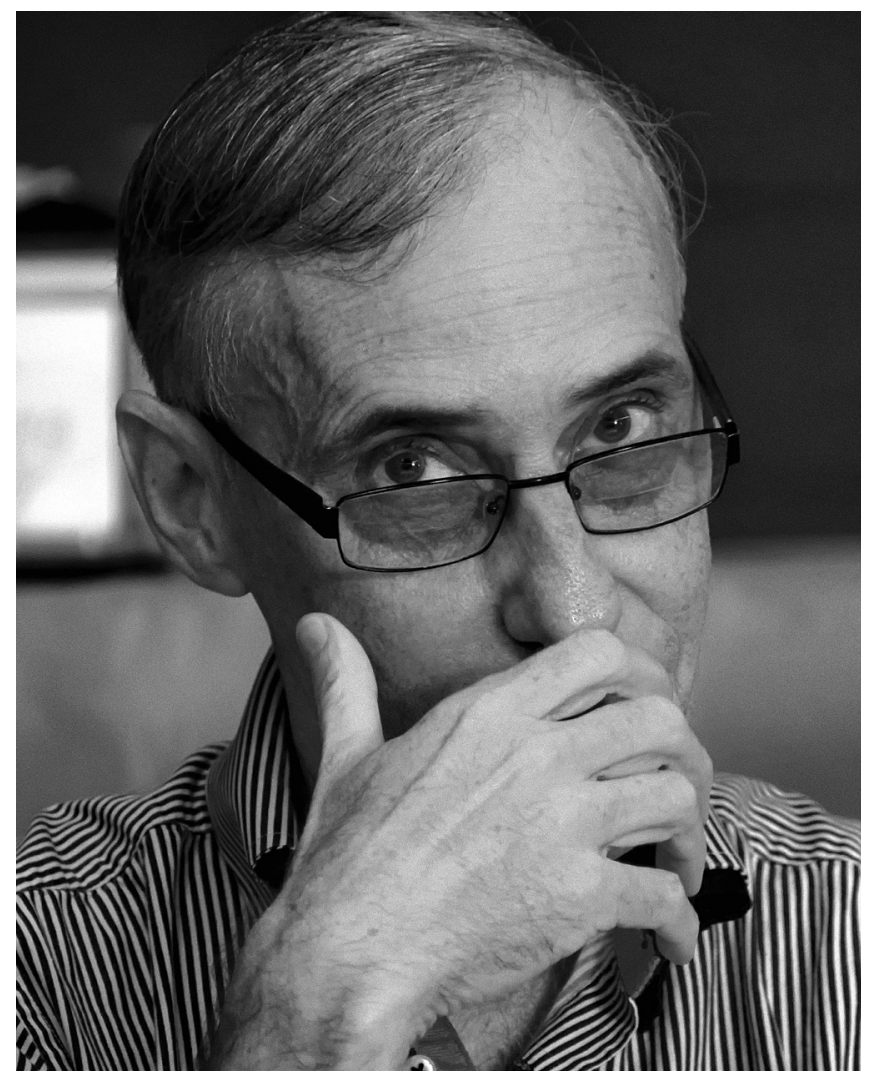

José Manuel Fernández Pequeño (Bayamo, 1953) es un escritor cubano que se mueve entre la crítica, el ensayo, la investigación y, sobre todo, la narrativa. Tiene una carrera literaria extensa y exitosa, con la publicación de cerca de una veintena de libros; ha sido profesor de varias universidades, editor de múltiples editoriales y publicaciones literarias y culturales especializadas, y ha recibido un buen manojo de premios, entre los que se destacan el Premio Memoria (1997), de la UNESCO, y la Medalla de Oro de los Florida Book Awards (2014). Recientemente ha sido declarado ganador del Premio Anual de Literatura Infantil y Juvenil Aurora Tavárez Belliard en República Dominicana (2015) por su libro Bredo, el pez. ${ }^{1}$

1. Has ganado muchos premios en tu vida como escritor $y$, entre ellos, dos de literatura para nińos y jóvenes, el Iberoamericano Libresa (2003) y, ahora, el Premio Anual de Literatura Infantil y Juvenil en República Dominicana. ¿Por qué libros para nińos?

No soy un escritor de literatura para nińos y comienzo por pedir excusas a los especialistas en esta materia. Escribí las piezas que luego formaron Cuentos para Angélica porque me pareció la mejor manera de comunicarme con mi hija, entonces una niña. Las aventuras de Bredo, el pez sí fueron ideadas como una novela para nińos mayorcitos. Quise dejar un testamento emocional a mis descendientes nacidos en la República Dominicana y los Estados Unidos.

1. Especialista del Centro Cultural Español de Miami, Florida centroflorit@ccemiami.org 


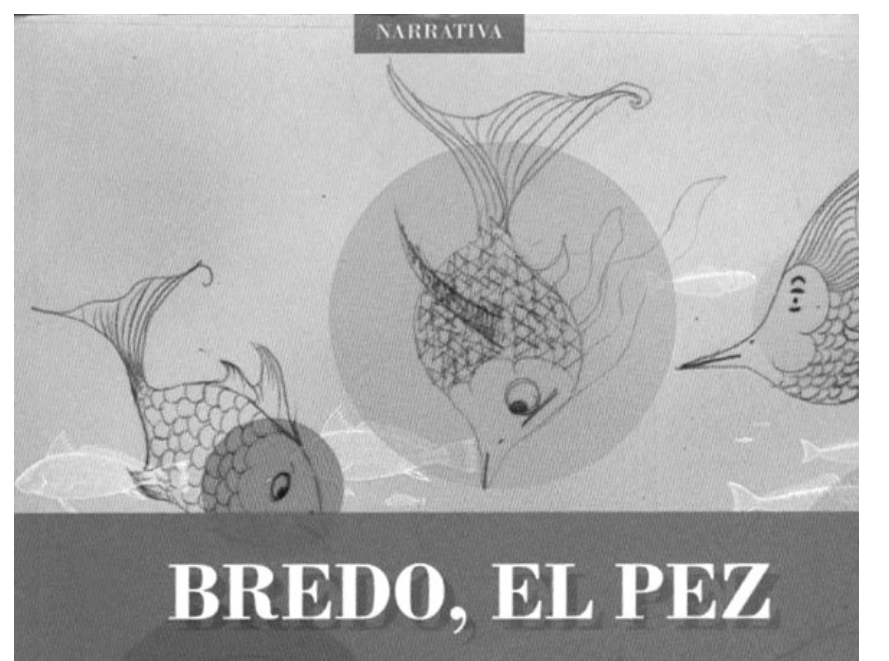

JOSÉ M. FERNÁ NDEZ PEQUEÑo

PREMHOANUAL DE LITERATURA INFANTIL "AERORA TAVÁREZ BELETARD” 2015

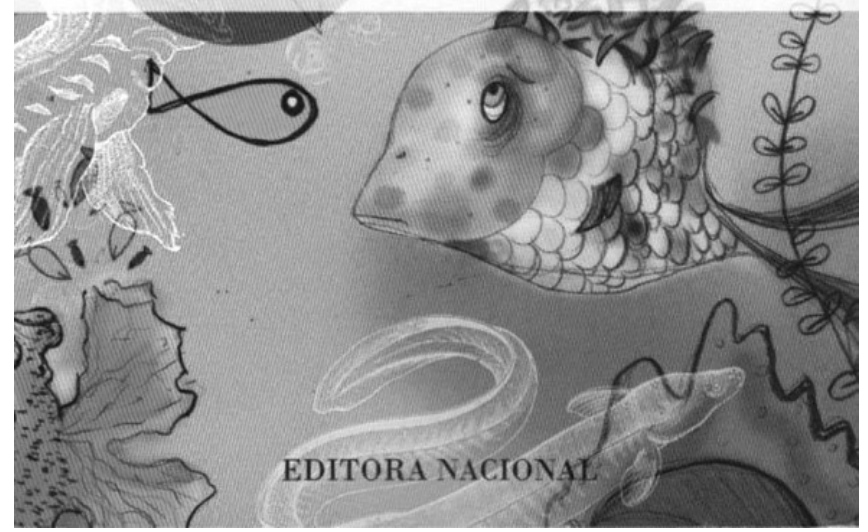

2. Muchas de tus imágenes en este libro son poéticas, como la de una piedra que solo habla cuando se le acaricia. ¿¿Habrase visto algo más loco que estar lleno de ternura y de lirismo... $y$, a la vez, resistirse con puños y dientes a escribir poesía?

Aunque quizás no lo parezca, soy un tipo extremadamente tímido y la comunicación literaria sin intermediarios (que eso son en realidad los narradores: intermediarios), se me hace difícil. Para sentirme cómodo al escribir, necesito el mirar sesgado y el decir sinuoso. En Bredo, el pez la apariencia de un decir poético pudiera provenir de su necesaria índole parabólica, de los paralelos simbólicos que establece entre la riquísima visualidad de la aventura en el fondo del mar y la experiencia de los seres humanos sobre la tierra.

3. Las moralejas del libro, aparte de la enseñanza que sirve de lección, ¿̨no será un primer intento público de poetizar?

Las moralejas del libro están escritas en décimas y no son un intento de hacer poesía, sino una forma de juego. Tienen más de broma para aliviar el componente didáctico, que de aspiración poética. Pero mira, ahora que lo mencionas, caigo en la cuenta de que esas cuatro décimas-moralejas, serán mis primeros versos publicados.

4. Hay en la novela ciertas frases que pueden considerarse alusiones.

Lo son. Ese es el centro conceptual de un texto que fue escrito como un homenaje a las novelas de aventura. Bredo debe aprender a cuestionar la mentira que lo mantiene encerrado en el estanque, romper con la compleja elaboración de reglas y símbolos que legitiman el sistema de sumisión, iniciar el duro aprendizaje de la libertad y, sobre todo, comprender que esa libertad resulta inviable si él no es capaz de asumir la enorme cantidad de riesgos que el mar abierto le plantea. Al final, de eso se trata: del coraje que cada quien necesita para tomar el control de su vida y hacerse responsable por sus decisiones.

5. ¿Te apoyas en la filosofía a la hora de escribir para niños? ¿Temes salirte de la supuesta línea o te importa un bledo desvirgarlos filológicamente hablando?

Me apoyo en la fuerza que generan las contradicciones; en el coraje que emana del miedo. El niño lector de hoy no es el que fuimos nosotros. Estos se van a Google o a YouTube y, en dos segundos, averiguan si lo que cuentas tiene visos de realidad o si los estás tomando por tontos. Hace muy poco le pedí su opinión sobre el texto a mi nieto mayor, que acaba de entrar a los diez años. Él leyó y me dijo: "A esto le faltan dibujos". ¡Imagínate tú! 
6. Tengo una teoría sobre la soledad del escritor que trata de destruir ese legendario mito. ¿Es o no un mito la soledad del escritor?

Es un mito, un intento de compensar el, generalmente, escaso éxito del escritor dentro del mundo social práctico. Tal soledad resulta cada vez más insostenible: la horizontalidad de la educación ha cerrado la brecha entre el escritor y sus lectores, en tanto que la horizontalidad de las comunicaciones nos expone a tal diversidad de mensajes que ni enterrándonos diez metros bajo tierra, lograríamos estar solos. El día llegará en que el escritor podrá escribir conectado con sus lectores, retroalimentándose directamente de ellos. Esto ya es común entre los artistas visuales contemporáneos, aunque aún despierta muchas reservas entre los escritores... pero hacia ahí vamos.

7. ¿Nunca has sentido el leve deseo de que alguien en algún lugar repita un texto tuyo?

No, no se me ocurriría. Por lo general ando muy ocupado escuchando maneras de decir que llegan desde todas partes, examinando detalles que están donde menos los imaginaba, forcejeando con historias que cuentan ciertas voces dentro de mí y yo ni sé adónde me llevan. El asombro me ocupa mucho tiempo de vida. Así que, si alguien repitiera de memoria una línea firmada por mí, casi seguro estaría repitiendo algo que escuché decir en casa, en la barbería, en una bebentina con amigos o a un paseante desprevenido en la calle. ¿Por qué habría de ponerme orgulloso entonces?

8. Eres un escritor que vive y escribe entre dos épocas. Hay quien dice que los que nacieron en el mundo digital prescinden de la profundidad y son más frívolos, más suaves, pero también más humanos, porque les preocupan menos cosas... ¿Son en realidad más humanos?

Son igual de humanos, solo que distintos porque han sido formados con otros códigos sociales. $\mathrm{Su}$ cerebro se organiza a través de instrumentos culturales diferentes. Vi una computadora por primera vez cuando iba camino a cumplir los cuarenta. Como toda mi generación, soy un sobreviviente, alguien que se vio obligado a cambiar de tren a mitad del viaje. Pero, también me hace feliz saber que puedo manejarme en ambos códigos, que soy virtualmente bilingüe. Alguna ventaja debe provenir de ahí.

\section{9. ¿Diderot y Voltaire o Bill Gates y Mark Elliot Zuckerberg?}

Los cuatro y todos los demás. Escribo para entender la vida, así que todo sirve, hasta aquello que detesto. De cualquier parte viene el dato o el motivo que necesito para seguir tecleando.

10. Si como lectores nos dejamos transportar por la impronta tecnológica y nos conformamos con leer lo breve, ignorando detenernos a degustar una buena y densa literatura, ¿no estaría eso reduciendo nuestra capacidad de ser mejores personas? ¿No estamos destruyendo el mundo intelectual con la premura?

Cierto, el que lee literatura dialoga consigo mismo a través del texto. Ahora bien, sería necesario definir qué estamos entendiendo por "lectura". Si la reducimos solo a los códigos verbales o al formato impreso sobre papel, entonces sí, hoy se lee menos. Pero, si entendemos por lectura la decodificación de cualquier código, sea verbal o no verbal, aparezca en el formato que aparezca, entonces debemos convenir en que nunca se ha leído tanto como hoy. Antes de arremeter contra las tecnologías debemos recordar que el libro es resultado de ese mismo desarrollo tecnológico que nos ha traído hasta aquí, y que cuando apareció como formato, no pocas voces se levantaron para protestar porque iba a destruir la cultura. Este es un viaje no exento de riesgos, pero las tecnologías de hoy solo cambiarán el universo intelectual, lo harán diferente. Igual que hizo el libro impreso en su tiempo. 
11. Generalmente escribes cuentos largos. ¿Qué te detiene a seguir... y seguir... y llegar a la novela?

No lo sé. En ese plano soy como un médium y me dejo llevar por impulsos. La novela requiere una planificación consciente a la que me he acercado a veces en los últimos tiempos. Por ejemplo, para escribir el relato El arma secreta. Así, a lo mejor en cualquier momento brinco la cerca del final cerrado que tanto me gusta en los cuentos y sigo derechito hacia la novela.

\section{2. ¿No crees que el cuento, como la novela, ten-} ga muchas leyes, y una perspectiva esquemática que debe romperse ya?

La historia de ambos, el cuento y la novela, ha sido un continuo intento de ruptura. Tanto el cuento como la novela abarcan hoy una cantidad de manifestaciones y formas extremadamente variadas. Por ejemplo, entre una microficción y un relato cabe casi todo... hasta la poesía. Ahora, sentarse a escribir un cuento teniendo en mente leyes o esquemas, debe ser un terrible sufrimiento y me parece más propio de escritores que trabajan con un objetivo no directamente vinculado con la expresión literaria, sino al resultado que se espera esta tenga sobre el lector; es decir, gente que escribe para entretener, ganar popularidad, hacer crítica social o conseguir dinero. Para mí, hay una historia que contar y a eso se reduce todo. Es un acto de libertad, ajeno a las reglas y los esquemas, en el que nunca presupongo quién será el lector. Con una excepción: lo que he escrito para niños.

\section{Nunca te he escuchado hablar con pasión de los grandes como Galdós, Balzac o Dostoievski ni siquiera de Cortázar, con quien tienes más de una afinidad (como el amor al fútbol), como lo haces cuando hablas de José Soler Puig. ¿̨No te habrás quedado en el gueto?}

Comencemos por el mundo. Me formé en un medio donde los héroes eran divinos. Puro engaño. He vivido en sociedades cada vez más asediadas por la farándula, que diviniza la belleza, la fortaleza, la habilidad o el poder de ciertos individuos. Puro engaño. Por todas partes aparece gente que talla una figura y no solo te dice "este es Dios", sino que además quiere que te arrodilles y comiences a rezar. Puro engaño. Nada sobre la tierra está exento de ser sometido a cuestionamiento, y eso incluye a los escritores reconocidos. Difícilmente podría haber aprendido algo de ellos si los hubiera observado con adoración. Para usar tus ejemplos: Galdós no me parece un narrador excepcional; Balzac sí, pero solo a veces; de Cortázar he leído su Rayuela en más de veinte ocasiones, pero prefiero sus cuentos; sobre Dostoievski me resulta difícil hacer juicios muy razonados, cada vez que leo obras como Crimen y castigo me paso semanas con pesadillas. Una vida ya larga y no pocos fracasos me han enseñado que la libertad personal radica en no ser incondicional de nada ni de nadie.

Y terminemos en el barrio. Nunca pertenecí a un taller literario. Nunca fui parte de un grupo de escritores. He sido un narrador periférico, cuando no antagónico a los modos de narrar dominantes durante los ańos 1970, 1980 y 1990 en Cuba, y solo comprendí mi verdadero signo el día que supe, ya viviendo en la República Dominicana, que tengo una única obligación como escritor: escribir historias que solo yo puedo contar de esa manera. Otros podrán contarlas mejor, pero no de la forma que se me han cocinado adentro. El resto es accesorio. Como ves, carezco de gueto donde quedar atrapado. Soler Puig fue un gran novelista que conocí de cerca. De él aprendí en la práctica que todo narrador necesita formar su oficio personal a puros coñazos. Él había formado el suyo a partir de otros grandes escritores, como el chileno José Donoso o el mexicano Carlos Fuentes. Visto desde esa perspectiva, ¿dónde quedan, entonces, los límites entre el barrio y el mundo?

\section{Datos de filiación}

Ena Columbié: Es licenciada en Filología. Ha obtenido numerosos premios en crítica literaria y 
artística, cuento y poesía. Tiene publicados los libros: Doscuentos (Narrativa. Cuba, 1987), ElExégeta (Crítica literaria. Cuba, 1995), Ripios y Epigramas (Poesía. USA-2001), Ripios (Poesía.USA-2006), Solitar (Poesía USA, 2012) Y Las horas (Antología, USA, 2011). Ha sido publicada en las antologías: Lenguas Recurrentes (Cuba, 1982), Lauros (Cuba, 1989), Epigramas (Cuba, 1994), Muestra Siglo XXI de la poesía en español (USA, 2005), La Mujer Rota (México, 2008) y Antología de la poesía cubana del exilio (España, 2011). Co-dirige las editoriales,
Entre Ríos y Alpha Beta. Ha colaborado en publicaciones como La Araña pelúa, de París, y las revistas norteamericanas La Peregrina Magazine, Linden Lane Magazine, ¿Qué pasa? y Decir del agua. Reside en Miami, Florida, y también muchas de sus obras, tanto de fotografía como de pintura, forman parte de colecciones privadas y de galerías. Ha expuesto en Ecuador, México y Estados Unidos. Dirige el blog de Ensayo y Crítica artística y literaria $E l$ Exégeta.

E-mail: centroflorit@ccemiami.org 